\title{
Economic Impact of THE PLAYERS Championship Golf Tournament at Ponte Vedra Beach, Florida, March $2005^{1}$
}

Tom Stevens, Alan Hodges, and David Mulkey²

Since the early 1980s, THE PLAYERS Championship (TPC) golf tournament has been held during the last week of March at the Sawgrass Stadium Golf course in Ponte Vedra Beach, Florida. This event is part of the PGA TOUR and is operated by PGA TOUR, Inc., which is also headquartered in Ponte Vedra Beach, Florida. In 2005, the TPC featured the largest purse ( $\$ 8$ million) of more than 50 PGA Tour tournament events held in the United States that year. Ponte Vedra Beach is located in the northeastern corner of St. Johns County, Florida, about 25 miles from Jacksonville (to the northwest) and St. Augustine (to the south). Shortly after the TPC event, PGA TOUR, Inc. requested the Food and Resource Economics Department at the University of Florida to conduct an analysis of the event's economic impacts on northeast Florida (Baker, Clay, Duval, Flagler, Nassau, Putnam and St. Johns Counties).

Based on a mathematical model of the regional economy, input-output analysis can be utilized to estimate how revenues from events like the TPC impact a regional economy. Impacts can be estimated in terms of sales, income, jobs, and taxes for specific types of businesses and institutions in the region.
Estimating these economic impacts makes it possible to assess the importance of THE PLAYERS Championship Golf Tournament to the regional economy as a whole and to the array of industries and institutions within that economy.

For the 2005 TPC event, the PGA Tour Inc. contracted EventCorp Service, Inc. to conduct an onsite survey of attendee characteristics, behaviors, and expenditures. Slightly over 2,400 usable questionnaires were completed, and summary statistics on attendee place of residence, length of stay, onsite and offsite expenditures, and overnight accommodations were computed from these questionnaires. PGA TOUR, Inc. estimated that total attendance (ticket sales) to the event over a six-day period was 180,000. Respondents to the EventCorp survey indicated that the number of days they attended the event, on average, was 2.5. From these two numbers, it can be estimated that there were approximately 72,000 attendees at the tournament. In addition, PGA Tour, Inc. reported that 1,267 players, caddies, officials, TV crews, marketing affiliates, and family members participated in or attended the event.

1. This is EDIS document FE698, a publication of the Food and Resource Economics Department, Florida Cooperative Extension Service, Institute of Food and Agricultural Sciences, University of Florida, Gainesville, FL. Published October 2007. Please visit the EDIS website at http://edis.ifas.ufl.edu.

2. Tom Stevens, Post Doctoral Associate; Alan Hodges, Associate In; and David Mulkey, Professor and Associate Chair, Food and Resource Economics Department, Florida Cooperative Extension Service, Institute of Food and Agricultural Sciences, University of Florida, Gainesville, FL.

The Institute of Food and Agricultural Sciences (IFAS) is an Equal Opportunity Institution authorized to provide research, educational information and other services only to individuals and institutions that function with non-discrimination with respect to race, creed, color, religion, age, disability, sex, sexual orientation, marital status, national origin, political opinions or affiliations. U.S. Department of Agriculture, Cooperative Extension Service, University of Florida, IFAS, Florida A. \& M. University Cooperative Extension Program, and Boards of County Commissioners Cooperating. Larry Arrington, Dean 
Based on the survey results, it was estimated that nearly 45 percent, or 32,261 , of all attendees and participants to the tournament were nonlocals (i.e., resided outside the seven-county study area). Spending by non-locals represents "new" dollars entering a regional economy. These new dollars generate additional indirect and induced (multiplier) effects for an economy as local or regional businesses purchase inputs, proprietors, and employees spend earnings, and governments spend tax collections. In contrast, spending by locals or residents within a regional economy does not necessarily constitute a change in total spending within that region. Based on EventCorp Services survey findings, average onsite expenditures across all 72,000 attendees and participants were $\$ 77.37$ per day, totaling $\$ 14.5$ million for the event. Approximately 52.8 percent, or $\$ 7.7$ million, of these onsite expenditures were estimated to originate from local attendees, with the remaining \$6.9 million being spent by non-local attendees and participants. Total offsite expenditures by non-local attendees and participants were estimated at slightly over $\$ 36$ million. Total onsite and offsite expenditures by all attendees, participants, and associates were estimated to be $\$ 53.2$ million. It was calculated that over 85 percent, or $\$ 45.5$ million, of these total expenditures originated from attendees or participants who resided outside the study area.

To calculate the economic impacts of the tournament for northeast Florida, the estimated expenditures were allocated to the appropriate industry sectors and applied to an IMPLAN Professional input-output model of the study area (IMPLAN, 2002). From this model, the total economic impacts of the 2005 PLAYERS Championship Golf Tournament were calculated to equal \$95.8 million in output or gross sales revenues; $\$ 59.9$ million in value-added; $\$ 40.7$ million in labor income, or net earnings; $\$ 6.0$ million in indirect business taxes; and 1,398 full- and part-time jobs for northeast Florida (Table 1). Induced effects, which result from subsequent expenditures of earnings by households of employees and proprietors, represented the largest source of economic impacts attributable to spending by non-local attendees and participants at the event.
The top four two-digit North American Industry Classification System (NAICS) aggregate sectors impacted by the tournament were Accommodation and Food Services; Retail Trade; Arts, Entertainment, and Recreation; and Government (Table 2). Accommodation and Food Services reaped 23.5 percent, or more than $\$ 22.5$ million, of the event's total output impacts. Retail trade came in second with 13.5 percent, or $\$ 12.7$ million, in output impacts, followed closely by Arts, Entertainment, and Recreation at $\$ 10.5$ million, and Government at slightly over $\$ 9.8$ million.

According to the Bureau of Economic Analysis, the seven-county region of northeast Florida had net earnings of $\$ 29.5$ billion and employment of 795,246 in 2004 (USC/BEA, 2005). Thus, this single event was equivalent to approximately 0.18 percent of the region's employment and 0.14 percent of the area's net earnings in that year. It should be noted that this analysis did not account for the impacts of daytime expenditures of attendees friends and family who did not attend the tournament. Also, there was no information collected on how the event influenced attendees and other audiences interest in visiting or moving to the area in the future.

\section{References}

PGA Tour, Inc., Ponte Vedra Beach FL. http://pgatour.com/info/company/about_us.

Minnesota IMPLAN Group (MIG). 2002. IMPLAN, Economic Impact and Social Accounting Software, and data for Florida. Stillwater, MN. http://www.implan.com.

U.S. Department of Commerce, Bureau of Economic Analysis, Regional Economic Information System, Personal Income and Employment Data. 2005. United Department of Commerce, Washington, D.C. http://www.bea.gov/bea/regional/reis/. 
Table 1. Economic impacts of attendee expenditures at THE PLAYERS Championship Golf Tournament, March 2005.*

\begin{tabular}{|c|c|c|c|c|c|c|}
\hline \multirow[t]{2}{*}{ Impact Type/Level } & \multirow[t]{2}{*}{ Units } & $\begin{array}{l}\text { Impacts from Local } \\
\text { Revenues }\end{array}$ & \multicolumn{3}{|c|}{$\begin{array}{c}\text { Impacts from Non-Local } \\
\text { Revenues }\end{array}$} & \multirow{2}{*}{$\begin{array}{l}\text { Impacts from All } \\
\text { Revenues }\end{array}$} \\
\hline & & Direct & Direct & Indirect & Induced & \\
\hline Output & \$ Million & 6.18 & 36.13 & 11.03 & 42.44 & 95.78 \\
\hline Value Added & \$ Million & 4.02 & 21.80 & 6.73 & 27.33 & 59.89 \\
\hline Labor Income & \$ Million & 3.35 & 14.64 & 3.78 & 18.93 & 40.71 \\
\hline Indirect Business Taxes & \$ Million & 0.47 & 2.98 & 0.57 & 1.95 & 5.97 \\
\hline Employment & Jobs & 122 & 693 & 99 & 484 & 1,398 \\
\hline
\end{tabular}

Table 2. Two-digit aggregate sector impacts from attendee expenditures at THE PLAYERS Championship Golf Tournament, March 2005.

\begin{tabular}{|c|c|c|c|c|c|c|}
\hline $\begin{array}{r}\text { IMPLAN } \\
\text { Sector } \\
\end{array}$ & $\begin{array}{l}\text { NAICS } \\
\text { Sector }\end{array}$ & Industry & Jobs & $\begin{array}{c}\text { Labor } \\
\text { Income }\end{array}$ & $\begin{array}{l}\text { Value } \\
\text { Added }\end{array}$ & Output \\
\hline & & Units & Jobs & \$ Million & \$ Million & \$ Million \\
\hline 1 & 11 & Agriculture, Forestry, Fish \& Hunting & 2 & 0.05 & 0.10 & 0.24 \\
\hline 19 & 21 & Mining & 0 & 0.00 & 0.00 & 0.00 \\
\hline 30 & 22 & Utilities & 2 & 0.18 & 0.52 & 0.75 \\
\hline 33 & 23 & Construction & 51 & 2.02 & 2.26 & 5.73 \\
\hline 46 & $31-33$ & Manufacturing & 13 & 0.56 & 0.86 & 2.66 \\
\hline 390 & 42 & Wholesale Trade & 20 & 1.18 & 2.12 & 2.93 \\
\hline 391 & $48-49$ & Transportation \& Warehousing & 55 & 1.36 & 1.88 & 3.63 \\
\hline 401 & $44-55$ & Retail Trade & 271 & 5.99 & 9.57 & 12.71 \\
\hline 413 & 51 & Information & 10 & 0.49 & 0.95 & 1.92 \\
\hline 425 & 52 & Finance \& Insurance & 22 & 1.24 & 2.17 & 3.96 \\
\hline 431 & 53 & Real Estate \& Retail & 39 & 1.01 & 3.28 & 5.70 \\
\hline 437 & 54 & Professional, Scientific \& Technical Services & 36 & 1.90 & 2.22 & 3.02 \\
\hline 451 & 55 & Management of Companies & 6 & 0.45 & 0.65 & 0.95 \\
\hline 452 & 56 & Administrative \& Waste Services & 35 & 0.87 & 1.04 & 1.73 \\
\hline 461 & 61 & Educational Services & 8 & 0.17 & 0.19 & 0.34 \\
\hline 464 & 62 & Health \& Social Services & 57 & 2.48 & 2.79 & 4.65 \\
\hline 475 & 71 & Arts, Entertainment \& Recreation & 141 & 5.56 & 7.15 & 10.50 \\
\hline 479 & 72 & Accommodation \& Food Services & 485 & 8.50 & 12.30 & 22.51 \\
\hline 482 & 81 & Other Services & 40 & 0.84 & 0.92 & 2.02 \\
\hline \multirow[t]{2}{*}{495} & 92 & Government \& Non-NAICS & 107 & 5.85 & 8.89 & 9.84 \\
\hline & & TOTAL & 1,398 & 40.71 & 59.89 & 95.78 \\
\hline
\end{tabular}

